\title{
Factor XIII
}

一瀬白帝 ${ }^{1-3 *}$

\section{Factor XIII}

Akitada ICHINOSE

要約：凝固第 XIII/13 因子(FXIII あるいはF13)は, トロンビンで活性化され，フィブリンを架橋結合して安 定化する。したがって，その先天性欠損症は重篤な出血症状を呈する．FXIII-A サブユニット(FXIII-A) と FXIII-B サブユニット (FXIII-B) からなり, 前者が触媒活性部位を持ち, 後者によって安定化される. 近年, FXIII が血管新生, 感染防御, 骨形成, 神経再生などにも働いている可能性が示されている. 遺伝子クローニン グにより構造機能関連のみならず先天性欠損症の分子病態的解析が進み, 欠損の分子機序も明らかになった. 欧米では組換え FXIII-A タンパク質製剤が登場し，新しい補充療法時代が到来した。一方，発展途上国では FXIII 活性定量検査試薬や FXIII 濃縮製剤が入手できず，国際間医療格差が拡大している。後天性 FXIII 欠乏 症はありふれた病態で，その重症型のみ出血症状を示す。その一部は抗 FXIII 自己抗体が原因の自己免疫性 出血(血友)病 XIII/13 であり，超高齢化社会に突入したわが国では症例数が年々増加し，昨年は年間 15 名に 達した，筆者らが，本疾患の診断基準「案」を作成したので，症例とその主治医の方々の参考用に提供する。

Key words: pleiotropic plasma transglutaminase, cross-linking reaction, autoimmune hemorrhaphilia, experts' recommendation, criterion and algorism

\section{1. はじめに}

先ず最初に, 日本血栓止血学会員の方々に, 2013 年 5 月 30 日から 6 月 1 日の 3 日間, 山形市で開催 させて頂いた「第 35 回日本血栓止血学会学術集会 しゃまがた大会」へのご協力，ご支援について厚く 御礼申し上げたい。御蔭様で交通不便な地方での開 催にも拘らず 900 名を超える方にご参加頂くことが でき，財政的にも学会に大いに貢献することができ た。「本当に有難うございました.」

${ }^{1}$ 山形大学医学部分子病態学講座

2 厚生労働科学研究費補助金（難治性疾患克服研究事業） 「後天性血友病 XIII（13）の実態調査, 発症機序の解明 と治療方法の開発」研究班

3 厚生労働科学研究費補助金 難治性疾患等克服研究事業 (難治性疾患克服研究事業)「診断困難な (原因不明の) 出 血性後天性凝固異常症の総合的診療指針の作成」研究班

*責任者連絡先： 山形大学医学部 分子病態学講座

干 990-9585 山形市飯田西 2-2-2

Tel: 023-628-5276, Fax: 023-628-5280

E-mail: aichinos@med.id.yamagata-u.ac.jp
さて，しゃまがた大会での会長講演でもお話した が，筆者は 1978 年に鹿児島大学を卒業して DICの 凝固パラメーターの解析をして以来，36 年間にわ たって凝固第 XIII/13 因子 (FXIII, ただし医療安全 のために臨床用には FXIII/13 と併記するか F13 と 記載する)の研究に携わってきた。 今回は, 野上編 集委員の「血液凝固研究/臨床最前線」の企画趣旨に 賛同して, FXIII 研究のトピックスと筆者らの到達 点について解説させて頂く.

\section{FXIII とは}

FXIII は，A サブユニット (FXIII-A)二量体と B サ ブユニット (FXIII-B) 二量体からなる異種四量体 $\left(\mathrm{A}_{2} \mathrm{~B}_{2}\right)$ として血中に存在するが, 巨核球/血小板, 単 球/マクロファージなどの骨髄系細胞の細胞質には FXIII-A 二量体のみが存在する ${ }^{1,2)}$. 一方, FXIII-B 二量体は肝細胞で産生・分泌され，骨髄系細胞から 未知の機序で放出される FXIII-A二量体と結合して, 互いに安定化しているものと考えられる(相互安定 
化仮説)。なお, 両サブユニットの遺伝子は 6 番, 1 番と別々の染色体に存在し, 遺伝子発現領域にも タンパク質分子構造にも共通性はないので, 進化の 過程で偶然親和性を獲得して協働するようになった もの(神様の実験) と推定される.

FXIII は, 凝固反応の最終段階で生じたトロンビン によって活性化され(FXIIIa)，フィブリン同士や フィブリンと $\alpha_{2}$-plasmin inhibitor, フィブロネクチン などのタンパク質の間に共有結合を形成して分子間 を架橋結合させる，その結果，フィブリンは安定化 され，物理的な力にも plasminのようなフィブリン 分解酵素に対しても抵抗性を増す。

したがって, その先天性欠損症では, 生涯続く重 篤な出血傾向や創傷治癒異常, 女性患者では不育 症/習慣性流産などの症状を呈する ${ }^{1,3)}$. 先天性 FXIII 久損症の頻度は 100 万人に 1 2 人と比較的稀であ る. FXIIIaは, 試験管内では多数のタンパク質を基 質とするが, その機能に関連する臨床症状が先天性 FXIII 欠損症で認められないので, それらの反応の 生体内での意義は不明である.

\section{3. 基礎研究におけるトピックス}

ゲノム時代からポストゲノム時代へ；1986年に筆 者がシアトルのワシントン大学で F13-A, F13-B 遺 伝子をクローニングして以来, その構造機能関連 ${ }^{4}$ や遺伝子発現調節機構, 3 次元構造の解析が分子生 物学的手法を用いて進められた。現在では，血管新 生, 感染防御 ${ }^{5}$, 炎症, 骨・軟骨形成, 視神経再生 ${ }^{6}$ などの機能に焦点を当てた研究が言わば「百花繚乱」 の状態であるが',2)，残念ながらそれらの機能に関 連する臨床症状は先天性 FXIII 欠損症で確認されて いない. 生体機能は多くの場合複数の経路/反応系 で支えられているので, FXIII 依存性の経路一つだ けが障害されても影響がみられない可能性がある (いわゆる redundancy 圥長性).

最近, プロテオーム解析で数十種のタンパク質が FXIII の基質として同定された ${ }^{7)}$. 筆者の経験では, 試験管内で FXIII を働かせると，多くのタンパク質 が表面にある Gln残基にアミノ基質を取り込むし， 自己架橋結合する。複数のタンパク質の間でも同様 に架橋結合が生じる(未発表データ). Bioinformatics
と生化学, 生理学などと協働した包括的理解が不可 欠である。

血栓止血領域の話題; 今月, FXIII が静脈血栓中の 赤血球の停留に関与しているという報告がされた ${ }^{8)}$. これは, 古くからヒト先天性 FXIII 欠損症の全血で 認められていた現象であり, 静脈血栓症の進展の阻 止にFXIII 阻害薬を用いる可能性が提唱されてい る. 全血の血栓は血漿の血栓よりも線溶抵抗性が高 いので，合理的なアイデアである。

筆者らは F13- $A, F 13-B$ 遺伝子ノックアウト $(\mathrm{KO})$ マウスを用いて,「症候と現象の観察から本態と本 質の解明」を目指しているが, 今のところヒト先天 性 FXIII 欠損症の病態を再現して詳細に機序を解析 しただけに留まっている。最近も，F13-A KO マウ スに拈ける血餅退縮欠如の観察から「FXIII-FibrinGPIIb/IIIa-Actomyosin Axis」仮説を展開したが9)，ヒ トでは必ずしも必須ではなく副次的に働いていると 思われるので，種の違いを痛感した次第である，た だし，前述した両サブユニットの「相互安定化仮説」 は，KO マウスを用いた生体内研究の結果であり， 研究手法の適切な評価と実施が必要であることは言 うまでもない.

前世紀からの宿題；1986年のクローニング当時か ら今も残されている最大の謎は, $\mathrm{N}$ 末端に分泌シグ ナルペプチドを持たない FXIII-A が細胞質から細胞 外に放出される機構である。われわれは以前「細胞 死による放出仮説」を提唱したものの, 以後「細胞 内, 核内, 細胞膜表面への移動」も観察しており(未 発表データ), いまだに模索を続けている。他の研 究グループも同様に FXIII-A が細胞質内を移動する ことを報告しているが，細胞外への放出は確認され ていない.

\section{4. 臨床研究におけるトピックス}

F13 遺伝子の多型性 : 90 年代から F13-A 遺伝子 Single Nucleotide Polymorphism が血栓症, 出血性疾患, その他の疾患/病態の危険因子であるという夥しい 報告があるが, 何れも弱い相関に留まっている，著 者らは, F13-B 遺伝子についてアレル特異性完全択 一的スプライシングが，モンゴロイド特異的アレル の原因であることを証明した。ただし，その臨床的 
意義については異論があり，定まっていない。 先天性 FXIII 欠損症の病態; 本態が不明であった先 天性 FXIII 欠損症については, 筆者らが 1990 年代 に遺伝子解析した結果それぞれFXIII-A 欠損症, FXIII-B 欠損症を新しく定義して分類し, 先天性欠 損症を惹起する機序について分子生物学的に解析し たので ${ }^{10)}$, その分子病態と症状, 重症度, 補充療法 との関係などが明らかにされている。また，近年， 女性欠損症例の反復性流産, 周産期の過剩出血の詳 細についての理解も進んでいる1 ${ }^{1}$.

発展途上国の症例；重大な問題は，世界人口の多く を占める発展途上国において FXIII 活性の定量的測 定方法, FXIII 濃縮製剤の供給が無いために先天性 欠損症の多くが見逃されたり，十分なケアを受けら れないことである。前者については筆者らも新しい 測定法の開発に取り組んでいるが, 後者は経済的問 題なので残念ながら解決は困難である.

組換え FXIII-A タンパク質製剂の登場；シアトルで のクローニング開始から 30 年後, ようやく組換え FXIII-A タンパク質製剤の市販が欧米で開始され た 白人の遺伝子産物なので日本人の FXIII-A とアミノ 酸配列の違いがあり, 市販されてからも抗原性につ いての注意が必要である.クローニングしてべク ターを作成して提供した本人(筆者)が， ある症例の 治療のために供与を申し入れたが，250万円支払え ば OK という回答であった。企業の論理とはそうい うものなのであろう.

血中 FXIII レベルと出血; 前世紀までは, 止血に必 要な FXIII 活性レベルは1〜 5\%であり, 先天性欠損 症のへテロ接合体は出血しないと言われてきたが, 現在は, 正常の $17 \%^{12}$ あるいは約 $50 \%{ }^{13,14)}$ でも止 血負荷時には過剩/異常出血するので加療が必要で あるというパラダイムシフトが起きつつある。

出血性後天性 FXIII 欠乏症; 今世紀の最大の問題は, 超高齢化社会の到来と共に, 出血性後天性凝固異常 症が増加しつつあることである，とくに，「自己免 疫性出血病 FXIII/13」については, 筆者らが 2009 年 から厚労科研の研究班を組織して全国的な調査活動 を実施し，世界の研究と臨床を先導している，その 結果, 今世紀に入ってからも 10 年は年間 1 人か 0 であった症例数が, 平成 25 年度 (2013 年) は 15 人
になり, 平成 26 年 7 月 28 日現在合計 43 例に達して, 筆者は昼夜を問わず主治医とコンサルテーションし ている。

残念ながら, 研究班が診断した症例の約 2 割は出 血死しており，4 例は Dead On Arrival of Sample 検 体到着時死亡で, 実際には死後 1 週間から 4 カ月に 確定診断されている. 恐らく検査されずに見逃され ている症例が多いものと推定される. 少なくとも 1 割は年余にわたり治療中で, 寛解後の再燃もあるこ とから, 本疾患は「慢性難治性致死性疾患」であるの で長期観察が必要であると, 筆者はパラダイムシフ 卜を提唱している(診断基準案を参照).

以下に, 5 年間の班研究の成果をまとめた「診断 基準と検査アルゴリズム案」を紹介するので，日常 診療で症例に遭遇する可能性のある臨床医の方々に 参考にして頂き, 救命に貢献して頂きたい.

また，学会員の方々には，これを吒き台にした， 新しい日本血栓止血学会の診断基準や診療ガイドの 作成に協力して頂きたい，学会には国民と症例に対 して社会的責任があり，学会員の方々にはその認識 と自覚があると筆者は信じている.

最後のメッセージは, 以下の

「貴方も, 貴方のご家族も, 誰でもなりうる本疾患 に注意しましょう!!」

である。

\section{謝辞}

ここに記述した研究は, 長年にわたる文部省科学 研究費, 厚労省科学研究費, その他の財団助成金の 支援で行われた。関係各位に媣く感謝したい，また， 山形大学の惣宇利正善博士, 尾崎司博士, 渋江由里 子女史が研究の実施に協力した. 更に, 厚労科研「出 血性後天性凝固異常症」の研究班員は以下の通りで ある。ここに明記して, 深甚なる感謝の意を表する。 班員 (敬称略)；

一瀬白帝, 惣宇利正善, 尾崎 司, 松下 正, 浦野 哲盟, 家子正裕, 玉井佳子, 伊藤俊広, 川前金幸, 山本正雅, 空岩清治, 黒澤秀光, 小川孔幸, 矢冨 裕, 花房規男, 川杉和夫, 石田文宏, 北島 勲, 朝倉英 策, 細野奈穂子, 毛利 博, 小林隆夫, 和田英夫, 宮田茂樹, 柏木浩和, 池田正孝, 湯川真生, 日笠 聡, 
羽藤高明, 岡本好司, 岡村 孝, 内場光浩, 橋口照 人，丸山征郎

\section{著者全員の利益相反 $(\mathrm{COI})$ の開示 :}

本論文発表内容に関連して開示すべき企業との利益 相反なし

\section{文献}

1) Ichinose A: Factor XIII is a key molecule at the intersection of coagulation and fibrinolysis as well as inflammation and infection control. Int J Hematol 95: 362-370, 2012.

2) Muszbek L, Bereczky Z, Bagoly Z, Komáromi I, Katona É: Factor XIII: a coagulation factor with multiple plasmatic and cellular functions. Physiol Rev 91: 931-972, 2011.

3) Kohler HP, Ichinose A, Seitz R, Ariens RA, Muszbek L; Factor XIII And Fibrinogen SSC Subcommittee Of The ISTH: Diagnosis and classification of factor XIII deficiencies. J Thromb Haemost 9: 1404-1406, 2011.

4) Smith KA, Pease RJ, Avery CA, Brown JM, Adamson PJ, Cooke EJ, Neergaard-Petersen S, Cordell PA, Ariëns RA, Fishwick CW, Philippou H, Grant PJ: The activation peptide cleft exposed by thrombin cleavage of FXIII- $\mathrm{A}_{2}$ contains a recognition site for the fibrinogen $\alpha$ chain. Blood 121: $2117-$ 2126, 2013.

5) Loof TG, Mörgelin M, Johansson L, Oehmcke S, Olin AI, Dickneite G, Norrby-Teglund A, Theopold U, Herwald H: Coagulation, an ancestral serine protease cascade, exerts a novel function in early immune defense. Blood 118: 25892598, 2011

6) Sugitani K, Ogai K, Koriyama Y, Kato S: Reciprocal changes in factor XIII and retinal transglutaminase expressions in the fish retina during optic nerve regeneration. Adv Exp Med Biol 801: 759-764, 2014.

7) Nikolajsen CL, Dyrlund TF, Poulsen ET, Enghild JJ, Scavenius C: Coagulation factor XIIIa substrates in human plasma: identification and incorporation into the clot. J Biol Chem 289: 6526-6534, 2014.
8) Aleman MM, Byrnes JR, Wang JG, Tran R, Lam WA, Di Paola J, Mackman N, Degen JL, Flick MJ, Wolberg AS: Factor XIII activity mediates red blood cell retention in venous thrombi. J Clin Invest. [Epub ahead of print] 2014

9) Kasahara K, Kaneda M, Miki T, Iida K, Sekino-Suzuki N, Kawashima I, Suzuki H, Shimonaka M, Arai M, OhnoIwashita Y, Kojima S, Abe M, Kobayashi T, Okazaki T, Souri $\mathrm{M}$, Ichinose A, Yamamoto N: Clot retraction is mediated by factor XIII-dependent fibrin- $\alpha \operatorname{IIb} \beta 3$-myosin axis in platelet sphingomyelin-rich membrane rafts. Blood 122: 3340-3348, 2013.

10) Zhang WG, Souri M, Ichinose A: Proteosomal degradation of naturally recurring R260C missense and exon-IV deletion mutants of factor XIII A-subunit expressed in mammalian cells. Haemophilia 19: 415-419, 2013.

11) Inbal A, Oldenburg J, Carcao M, Rosholm A, Tehranchi R, Nugent D: Recombinant factor XIII: a safe and novel treatment for congenital factor XIII deficiency. Blood 119: 51115117, 2012

12) Peyvandi F, Palla R, Menegatti M, Siboni SM, Halimeh S, Faeser B, Pergantou H, Platokouki H, Giangrande P, Peerlinck $\mathrm{K}$, Celkan T, Ozdemir N, Bidlingmaier C, Ingerslev J, Giansily-Blaizot M, Schved JF, Gilmore R, Gadisseur A, Benedik-Dolničar M, Kitanovski L, Mikovic D, Musallam KM, Rosendaal FR; European Network of Rare Bleeding Disorders Group: Coagulation factor activity and clinical bleeding severity in rare bleeding disorders: results from the European Network of Rare Bleeding Disorders. J Thromb Haemost 10: 615-621, 2012.

13) Seitz R, Duckert F, Lopaciuk S, Muszbek L, Rodeghiero F, Seligsohn U: ETRO Working Party on Factor XIII questionnaire on congenital factor XIII deficiency in Europe: status and perspectives. Study Group. Semin Thromb Hemost 22: 415-418, 1996.

14) Ivaskevicius V, Biswas A, Bevans $C$, Schroeder V, Kohler HP, Rott H, Halimeh S, Petrides PE, Lenk H, Krause M, Miterski $\mathrm{B}$, Harbrecht U, Oldenburg J: Identification of eight novel coagulation factor XIII subunit A mutations: implied consequences for structure and function. Haematologica 95: 956$962,2010$.

\section{自己免疫性出血病 XIII/ 13 の診断基準と 検査アルゴリズム研究班案 (JAPAN CRITERION FOR AH13 2012 ${ }^{\mathrm{a})}$ に加 筆・改訂)；日本版}

\section{同義語}

Factor XIII/13(FXIII/13)に対する後天性インヒビ ター, FXIII/13 インヒビター, フィブリン架橋結合/安 定化の後天性インヒビター, FXIII/13 に対する抗体/ $\mathrm{IgG}, \mathrm{FXIII/13}$ に対する自己抗体・自己免疫性抗体/イン ヒビターによる出血性疾患/障害等.

\section{1. はじめに}

抗 FXIII/13 抗体による自己免疫性出血病 (Autoimmune Hemorrhaphilia XIII/13, AHXIII/13)は, 主に高齢 者に起きる極めて稀な致死性の出血性疾患である ${ }^{\mathrm{b}, \mathrm{c})}$. 21 世紀の初頭, 超高齢社会に到達した日本で増加し つつあり, 計 46 日本人症例が確認されている。一方, 非日本人症例は世界中で合計 32 例が報告されている (2014 年 1 月 15 日現在)。本文の目的は, AHXIII/13 を正確, 容易, 且つ迅速に診断する為の検査と診断の アルゴリズムについての専門家の提案事項を周知させ ることである(図1). 


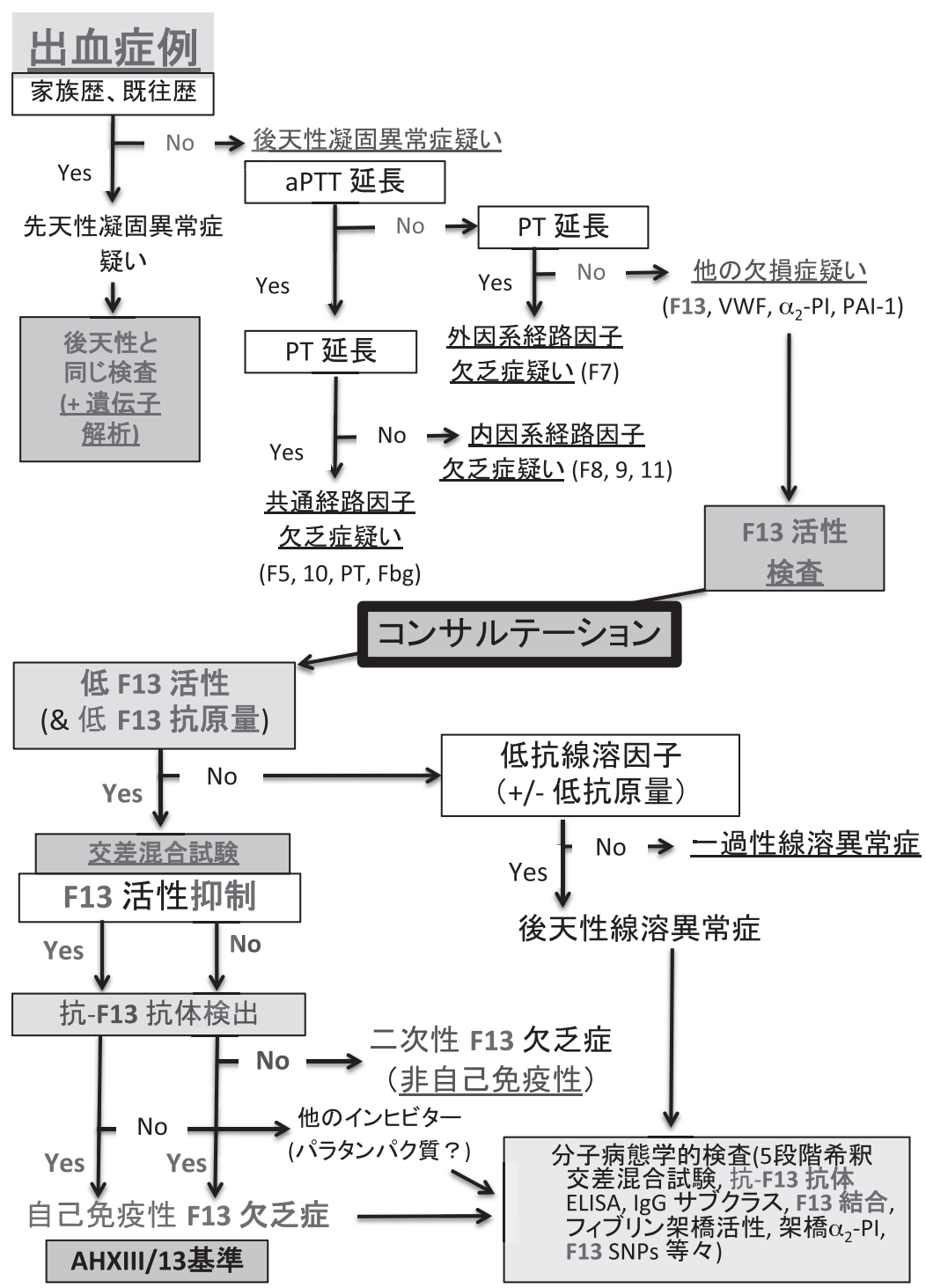

図 1 AHXIII/13 診断の為の検査アルゴリズム

表 1 AHXIII/13 の基礎疾患

（1）自己免疫疾患 (SLE，RA，シェーグレン症候群等)

(2) 全ての固形腫瘍

(3) 骨髄増殖性疾患

(4)リンパ増殖性疾患 (MGUS を含む)

(5)長期の薬剤投与 (INH，ペニシリン，プロカインアミド，抗精神疾患薬等)

(6)その他 (妊娠を含む)

\section{2. 定義}

AHXIII/13 とは, 特発性, あるいは様々な基礎疾患 や薬物が関与して生じた抗 FXIII/13 自己抗体がもた らす後天性 (非遺伝性) の FXIII/13 単独の障害/欠陥で
ある(表 1). 先天性/遺伝性 FXIII/13 欠損症に似て, 部位的，時間的に出血症状が多発する疾患である.

\section{3. 主要症状}

AHXIII/13 の臨床症状は, 多発性の皮膚・粘膜出血 
から致死性の体腔内出血に至るまで多彩である。症例 は，多様な合併する病態や病因機構(例えば，活性型 FXIII/13 に対する中和性自己抗体, 活性化の阻害, FXIII/13-A サブユニット，FXIII/13-B サブユニットに 結合性の自己抗体によるクリアランス克進等)を反映 して, 様々な重症度の出血症状を突然発症する。

簡略版国際血栓止血学会/科学㧍よび標準化委員会 の出血評価票 2010 年版 (Bleeding Assessment Tool ver. $2010^{\mathrm{d})}$ ；図 2)のような標準化出血質問票は, AHXIII/ 13 症例に扮ける上述したような多様な出血症状の正 確且つ客観的な評価に有用であろう。また，重症度分 類, ${ }^{\mathrm{e}}$ () (表 2) も同時に判定して, 重症例を見逃さないよ うに努めるべきである。

症例の半数は特発性と報告されているが，全例で基 礎疾患の検索を実施するべきである。

\section{4. 診断基準}

以下の項目に合う全ての症例では, AHXIII/13 を考 慮すべきである；

(1) 主に高齢者において最近発症した出血症状

(2) 先天性/遺伝性 FXIII/13 欠損症の家族歴が無い

（3）とくに過去の止血負荷 (手術や外傷等)に関係した 出血症状の既往歴が無い

(4) 抗凝固薬や抗血小板薬などの過剩投与が無い

(5) 検査上, FXIII/13 に関するパラメーターの異常が ある

(6) 抗 FXIII/13 自己抗体が存在する

\section{5. 検查所見 ${ }^{\mathrm{g})}$}

\section{(1) 一般凝固検查}

出血時間 - 殆どの症例では正常だが，基礎疾患に よっては延長していることがある.

PT と aPTT - 殆どの症例では正常だが, 先行する 出血による失血量や基礎疾患によっては延長している ことがある。

血小板数 - 殆どの症例では正常だが, 先行する出 血による失血量や基礎疾患によっては減少しているこ とがある。

\section{(2)特異的凝固検查}

FXIII/13 活性, FXIII/13 抗原量 - 通常, 両者とも低 下している。ただし，一部の症例，例えば，抗 FXIII/ 13-B 自己抗体が原因の症例では，病歴全体での時期 やFXIII/13 製剤による治療によって両者とも正常範 囲に近くなることがある，FXIII/13 単独の高度の低下 は AHXIII/13を疑い, 他の複数の凝固因子の低下を
伴って軽度〜中等度に低下する場合は DIC, 重度の肝 障害などによる二次性 FXIII/13 欠乏症であることが 多い.

FXIII/13 比活性 - 抗 FXIII/13-A 自己抗体が原因の 殆どの症例では低下しているが，抗 FXIII/13-B 自己 抗体が原因の症例では正常である。

FXIII/13-A, FXIII/13-B, FXIII/13- $\mathrm{A}_{2} \mathrm{~B}_{2}$ 抗原量 - 抗 FXIII/13 自己抗体のタイプ性状によって, 様々な程 度まで低下している。

\section{(3) 確定診断的検査}

FXIII/13 インヒビターの機能的検査 - これはア ミン取込み法やアンモニア放出法などを用いた混合検 査法で実施されるが，両者とも FXIII/13 活性化や活 性型 FXIII/13(FXIII/13a)の酵素活性を阻害する抗体の みを検出するので，注意が必要であるＦXIII/13 イン ヒビターを検出するスクリーニング法としては，症例 の血漿と健常対照の血漿を用いた $1: 1$ 交叉混合試験が 一般的である。 5 段階希䣋混合試験も，FXIII/13 低下 が「インヒビター型」であるか「因子欠乏型」であるかを 区別するのに有用である。FVIII/8 インヒビターの Bethesda 単位のように, 症例の検体を段階的希釈して 健常対照の検体と混合し，残存活性を測定することに より，FXIII/13 インヒビターの力価を決定することも 可能である.

抗 FXIII/13 自己抗体の免疫学的検查 - 必ずしも全 ての AHXIII/13 症例の原因が中和型/阻害型抗 FXIII/13 自己抗体の産生ではないので, 抗体の検出検査の実施 は必須である。非中和型/非阻害型抗 FXIII/13 自己抗 体は，ELISA が原理の方法や，イムノ/トットブロッ トアッセイ，イムノクロマトグラフイ法等を用いた抗 原抗体結合検査法で検出されている。理論的には，二 次性 FXIII/13 欠乏症に偶然合併した，無害な FXIII/13 結合抗体もあり得るが，その場合は基礎疾患の治療に より, 出血症状も消失する.

\section{6. 治療試験/追加検査}

（1） FXIII/13 製剤投与試験；AHXIII/13 の診断を，治療 試験である程度明らかにできることがある；AHXIII/ 13 の病因や抗体の性状によっては, FXIII/13 を含有す る濃縮血液製剤の投与後クリアランスの充進が確認さ れる。これは，次回からの FXIII/13 製剤の投与量や 投与間隔等の止血治療計画を立てる上でも有用であ る。

(2) フィブリン $\gamma$ 鎖， $\alpha$ 鎖の架橋結合反応; 即ち， $\gamma$ 鎖 二量体化， $\alpha$ 鎖多量体化は，それぞれ通常著しく遅延 
ISTH/SSC 出 血評 価 票 (日本語試用版*1)

\begin{tabular}{|c|c|c|c|c|c|}
\hline 症例の & 匿名化暗号: & & 調査年月日: & 性別: & 生年月: \\
\hline 評価時(何れかに○) & 最重症期 - & 初診時 · 診断時· & \multicolumn{3}{|c|}{ 治療前 - 治療後 - 治癒後 - 寛解後 } \\
\hline \multirow{2}{*}{ 症状 } & \multicolumn{5}{|c|}{ 出血スコア } \\
\hline & 0 & 1 & 2 & 3 & 4 \\
\hline 鼻出血 & 無しか 軽微 & $\begin{array}{l}\cdot \text { 年5回以上 } \\
\cdot 10 \text { 分間以上 }\end{array}$ & 診察／検査のみ & $\begin{array}{l}\text { パツキング か 焼灼術 か } \\
\text { 抗線溶薬 }\end{array}$ & $\begin{array}{l}\text { 輸血 か 補充療法(止血因子、 } \\
\text { rFVIIlaの使用) (か デスモプ } \\
\text { レッシン)*2 }\end{array}$ \\
\hline 皮䖉の(出血) & 無しか 軽微 & $\begin{array}{l}\begin{array}{l}\text { 露出部に年5回以上の挫創 } \\
\text { (1 cm以上) }\end{array} \\
\end{array}$ & 診察／検査のみ & 広範囲 & 自発性血腫で輸血が必要 \\
\hline 軽度外傷からの出血 & 無しか 軽微 & \begin{tabular}{|l} 
年5回以上 \\
$\cdot 10$ 分間以上 \\
\end{tabular} & 診察／検査のみ & 手術による止血 & $\begin{array}{l}\text { 輸血 か 補充療法 (か デスモ } \\
\text { プレッシン) }\end{array}$ \\
\hline 口腔(内出血) & 無しか 軽微 & 有り & 診察／検査のみ & 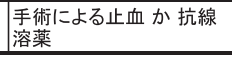 & $\begin{array}{l}\text { 輸血 か 補充療法 (か デスモ } \\
\text { プレッシン) }\end{array}$ \\
\hline 胃腸管出血 & 無し か 軽微 & $\begin{array}{l}\text { 有り(潰瘍、門脈圧え進症、 } \\
\text { 痔、㿼形成異常に伴わな } \\
\text { ( ) }\end{array}$ & 診察／検査のみ & \begin{tabular}{|l|} 
手術による止血 か 抗線 \\
溶薬
\end{tabular} & $\begin{array}{l}\text { 輸血 か 補充療法 (か デスモ } \\
\text { プレッシン) }\end{array}$ \\
\hline 血尿 & 無し か 軽微 & 有り(肉眼的) & 診察／検査のみ & \begin{tabular}{|l|} 
手術による止血 か 鉄剂 \\
投与
\end{tabular} & $\begin{array}{l}\mid \text { 輸血 か 補充療法 (か デスモ } \\
\text { プレッシン) }\end{array}$ \\
\hline 抜歯 (時出血) & \begin{tabular}{|l} 
無しか 軽微 \\
か 未施術 \\
\end{tabular} & \begin{tabular}{|l|} 
全ての施術の25\%以下で \\
報告/申告、無介入 \\
\end{tabular} & \begin{tabular}{|l|} 
全ての施術の25\%以上で \\
報告/申告、無介入
\end{tabular} & 再縫合 か パッキング & $\begin{array}{l}\text { 輸血 か 補充療法 (か デスモ } \\
\text { プレッジン) }\end{array}$ \\
\hline 手術(関連出血) & \begin{tabular}{|l} 
無しか 軽微 \\
か 未施術 \\
\end{tabular} & \begin{tabular}{|l|} 
全ての施術の25\%以下で \\
報告/申告、無介入 \\
\end{tabular} & \begin{tabular}{|l|}
$\begin{array}{l}\text { 全ての施術の25\%以上で } \\
\text { 報告/申告、無介入 }\end{array}$ \\
\end{tabular} & $\begin{array}{l}\mid \begin{array}{l}\text { 手術による止血 か 抗線 } \\
\text { 溶薬 }\end{array} \\
\end{array}$ & \begin{tabular}{|l} 
\\
輸血 か 補充療法 (か デスモ \\
プレジ)
\end{tabular} \\
\hline 過多月経 & 無しか 軽微 & $\begin{array}{l}\text { 診察/検査のみか } \\
\text {-2時間おき上頻繁にパッ } \\
\text { ド交換 か } \\
\text { ·凝血塊を伴う多量出血 } \\
\text { 経血量図評価チャートスコ } \\
\text { ア100坚上 } \\
\end{array}$ & $\begin{array}{l}\text { ·年2回以上の欠勤/久席 } \\
\text { か } \\
\text { •抗線溶薬 か 女性ホルモ } \\
\text { ンか 鉄剂投与必要 }\end{array}$ & $\begin{array}{l}\text { ·抗線溶薬と女性ホルモン } \\
\text { 両方必要 か } \\
\text { ·初経以来12ヶ月以上有 } \\
\text { り }\end{array}$ & $\begin{array}{l}\text { ·入院と緊急治療が必要な急 } \\
\text { 性出血 か } \\
\text { ·輸血 が 補充療法 (か デス } \\
\text { モブレツジ } \\
\text { ·子宮内容除去術 か子宮内 } \\
\text { 膜焼灼 か 子宮摘出術必要 }\end{array}$ \\
\hline 産後出血 & $\begin{array}{l}\text { 無し か 軽微 } \\
\text { か 未分婏 }\end{array}$ & $\begin{array}{l}\text { 診察/検査のみか } \\
\text {-才キジ使用 } \\
\text {-6週以上の悪露 }\end{array}$ & \begin{tabular}{|l}
-鉄剤投与 か \\
-抗線溶薬
\end{tabular} & 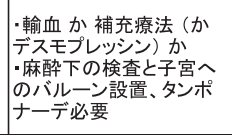 & $\begin{array}{l}\text { 緊急治療か 手術介入(子宮 } \\
\text { 摘出術, 内腸骨動脈結禁、子 } \\
\text { 亳動脈塞栓術か子容ブレース } \\
\text { 縫合)必要 }\end{array}$ \\
\hline 筋肉血腫 & 一度も無い & 外傷後で無治療 & 自発性で無治療 & $\begin{array}{l}\text { 自発性 か 外傷性で補充 } \\
\text { 療)法(か デスモプレッシ } \\
\text { シ)必要 }\end{array}$ & $\begin{array}{l}\text { 自発性 か 外傷性で手術介入 } \\
\text { 輸血必要 }\end{array}$ \\
\hline 関節出血 & 一度も無い & 外傷後で無治療 & 自発性で無治療 & $\begin{array}{l}\text { 自発性 か 外傷性で補充 } \\
\text { 療法(か デスモプレッシ } \\
\text { ン)必要 }\end{array}$ & $\begin{array}{l}\text { 自發性 か 外傷性で手術介入 } \\
\text { 輸血必要 }\end{array}$ \\
\hline 中枢神経系出血 & 一度も無い & - & - & 硬膜下出血で全ての介入 & 脳内出血で全ての介入 \\
\hline その他の出血 *3 & 無しか 軽微 & 有り & 診察／検査のみ & \begin{tabular}{|l|}
$\begin{array}{l}\text { 手術による止血 か 抗線 } \\
\text { 溶 }\end{array}$ \\
\end{tabular} & $\begin{array}{l}\text { 輸血 か 補充療法 (か デスモ } \\
\text { プレッシン) }\end{array}$ \\
\hline \multicolumn{5}{|c|}{$\begin{array}{l}\text { *1 Vicenza groupの協力を得て翻訳、一部改訂した(赤字部分) } \\
* 2 \text { (か デスモプレッシン)は後天性von Willebrand症候群用 } \\
* 3 \text { 体腔内(胸腔内、腹腔内など)の出血を含めて評価し、自由記入欄に詳述する }\end{array}$} & 合計点 \\
\hline
\end{tabular}

自由記入欄:

作成者: 一瀬 白帝 2014/2/7

図 2 国際血栓止血学会/科学掞よび標準化委員会の簡略版出血評価票 2010 年版 (Bleeding Assessment Tool ver. 2010 の $^{4}$ 日本語翻訳版 (A.I., F.R., A.T.により 2013 年 11 月に微修正)

なお, 鼻出血, 皮膚出血, 軽度外傷からの出血の既往 1 点は, 2 回目以降治療等によって消 失した場合は 0 点とする，異なる箇所に多発する出血は，その旨自由記入欄に記載する。 
表 2 出血性凝固異常症の重症度分類案 2014(Schulman et al., 2005; Baudo et al., 2012 の重症出血の定義を改変) , f) $^{\text {作 }}$

1. 重症出血：

(1) 致命的な出血

(2) 重要部位, 重要臓器の出血(例えば, 頭蓋内, 脊髄内, 眼球内, 気管, 胸腔内, 腹腔内, 後腹膜, 関節 内, 心囊内, コンパートメント症候群を伴う筋肉内出血等)

(3) $\mathrm{Hb}$ 值 $8 \mathrm{~g} / \mathrm{dL}$ 以下の貧血, あるいは $2 \mathrm{~g} / \mathrm{dL}$ 以上の急速な $\mathrm{Hb}$ 值低下をもたらす出血

(4) 24 時間内に 2 単位以上の全血あるいは赤血球輸血を必要とする出血

2. 軽症出血 ${ }^{*}$ :

上記以外の全ての出血 ${ }^{* *}$

* : 日本語版簡略版出血評価票 $(\mathrm{JBAT})$ も参考にすることを推奨

**; 多発性および有痛性の出血は, 重症に準じて止血治療を考慮すべき

別表 1 自己免疫性出血病 XIII/13 の治療指針案 2014(厚生労働省難治疾患調査研究班治療の指針案 2012 と JAPAN CRITERION FOR AH13 2012 を改訂）

A. 出血性後天性 FXIII/13 欠乏症全体

診断前止血治療；DIC が無ければ，とくに粘膜出血にトランサミン等の抗線溶薬の投与を推奨

持続的な止血を得るまで；1-2 g/日内服，点滴静注など(尿路出血には用いない)

B. 自己免疫性出血病 XIII/13 (自己抗体/インヒビター型 FXIII/13 欠乏症)

1)歨血治療；長期にわたる FXIII/13 濃縮製剤の大量投与 (中和抗体やクリアランスを古進させる抗体が

存在するので，先天性欠損症の治療時よりも多く投与し，適宜 FXIII/13 活性の上昇を確認)

重症出血 (頭蓋内，胸腔内，後腹膜など）；50 単位 $/ \mathrm{kg}$ 以上 (正常の活性約 $100 \%$ 以上を目標)

軽症出血(皮下，筋肉内など）；25 単位/ $\mathrm{kg}$ 以上(正常の活性約 $50 \%$ を目標)止血が得られた場合は, 数日後に投与終了(後出血がないことを確認)

2)抗体根絶治療(免疫抑制療法)；必ず診断直後から投与開始，できるだけ FXIII/13 濃縮製剤投与前に 開始(FXIII/13 は遺伝的多型性に富むので boost reactionの可能性を否定できない)

第一選択薬；副腎皮質ステロイド；0.5-1 mg/ $/ \mathrm{kg} /$ 日

第二選択薬；サイクロフォスファミド； $1-2 \mathrm{mg} / \mathrm{kg} /$ 日， $100 \mathrm{mg} /$ 日

保険適応外薬；リツキシミブ(上記薬に不応例, 糖尿病, 感染, 免疫不全合併例など）； $375 \mathrm{mg} / \mathrm{m}^{2} /$

週

その他；サイクロスポリン，アザチオプリン，タクロリムスなど

免疫抑制療法の終了は, インヒビターと自己抗体の陰性化を確認してから (FXIII/13 活性の正常

化を指標にする場合は, 必ず複数回確認してから)

数年間は再発に注意して必ず経過観察

やむを得ず免疫抑制療法をしない場合は，とくに注意深く出血の経過観察

C. 非自己免疫性出血性後天性 FXIII/13 欠乏症 (三次性FXIII/13 欠乏型)

1)止血治療；短期間の FXIII/13 濃縮製剤投与 (適宜 FXIII/13 活性の上昇を確認)；ただ，原因疾患の

根治が出来ない場合は，慢性欠乏症として対処

濃縮製剤投与終了の判定に FXIII/13 活性正常化を指標にする場合は，複数回確認

2) 原因疾患の治療

しているか欠如している。

(3) 架橋 $\alpha_{2}$-plasmin inhibitor $\left(\alpha_{2}\right.$-PI) (血漿 $\alpha_{2}$-PI から血 清 $\alpha_{2}$-PI を減じる); FXIII/13 活性が正常の $50 \%$ 以下 に低下すると，架橋 $\alpha_{2}$-PI 量と比率も低下する。たた

し, AHXIII/13 に特異的な検査所見ではない.

(4) 血小板内 FXIII/13 量; 正常量が検出されるので, 先天性 FXIII/13 欠損症の可能性を除外するのに有用 である。

AHXIII/13 を伴う基礎疾患の検索を実施することは不
可欠である.

\section{附 1. AHXIII/13 の治療（別表 1）}

(1) AHXIII/13 は，複数の FXIII/13-A あるいは FXIII/ 13-Bに対する自己抗体を伴う複雑な疾患であり，両 方あるいは一方の FXIII/13 サブユニットの様々なレ ベルの低下がもたらされる。阻害型, クリアランス立 進型の違いや標的部位の違い, 重症度の違いなどに よって，細やかな個別化医療が必要となるので，本疾 
別表 2 統合的治療に対する反応の判定基準(試案)

1) 免疫学的寬解 (完全寛解) ; 出血症状, インヒビター, 抗 FXIII/13 自己抗体の消失が見られる(通常, 月 の単位)ただし, FXIII/13 活性，抗原量の正常化にはより長期間を要する.

2) 機能的寛解 (部分寬解 I 型) ; 出血症状と検査上のインヒビターの消失が認められるが，抗 FXIII/13 自己 抗体が存続する (通常, 週〜月の単位)

3) 臨床的寬解 (部分寬解 II 型) ; 出血症状の消失が認められるが, 検査上インヒビターと抗 FXIII/13 自己 抗体が存続する (通常, 日〜週の単位)

4) 無効；治療に全く反応しないもの

通常，適切な止血療法により 3)へ，抗体根絶療法により 2)，1)へと進む

別表 3 止血治療の効果判定基準(試案) $)^{\mathrm{h}}$

止血治療の効果は, 疼痛や腫脹などの臨床症状の軽減, 貧血の改善を参考にして判定する，以下は，止 血療法が無効であることを示すので，治療の再実施や方法の変更を検討する必要がある.

1)顕性出血; 単位時間当りの失血量 (速度)に変化なし

2)赤血球補充に拘らず $\mathrm{Hb}$ レベル不変, あるいは低下

3) 画像解析で体腔内, 器官臟器内出血のサイズ増大

4)的確な治療実施 48 時間後 (重要部位ならば 24 時間後)も継続する出血の証拠

5)止血治療中にも拘らず新しい部位へ出血

6)止血治療にも拘らず血腫に関わる疼痛の増大

7)国際血栓止血学会/科学㧍よび標準化委員会の簡略版出血評価票 2010 年版 (Bleeding Assessment Tool ver. 2010)の日本語版 (JBAT；図 2)で評価された出血スコア (BS)の増加あるいは変化無し

患に対する画一的な，明確な診療指針を示すのは困難 である. AHXIII/13 疑い症例は, 如何なる出血症状の エピソードの治療についても, 完全寛解に達するまで 凝固専門家に照会/相談するべきである(別表 2).

（2）止血治療；出血症状が起きた場合や，手術を含む 如何なる侵襲的な処置を計画する場合は, FXIII/13 含 有濃縮製剂(緊急に入手不能の場合は, 新鮮凍結血漿 も可)を使用する。ただし，自己抗体による FXIII/13 のクリアランス光進や活性阻害の為, 多くの場合, 輸 注に対する反応は比較的短い期間に過ぎないであろ う。また，阻害性抗体を凌駕したり，クリアランス京 進に対抗・均衡する為に, 通常先天性欠損症に投与す るより大量の投与が必要である。抗 FXIII/13-B 自己 抗体の症例では, 血漿由来 FXIII/13 濃縮製剤に含ま れる外来性の FXIII/13-B, 即ち FXIII/13- $\mathrm{A}_{2} \mathrm{~B}_{2}$ に対す る既往反応/免疫増幅効果 (ブース卜効果)のリスクを 減らす為に, 組換え FXIII/13-A 製歳を輸注するのが 合理的である，顕(在)性出血を停止させるまで，止血 治療を繰り返すべきである ${ }^{\mathrm{h}}$ (別表 3).

(3) 抗体根絶治療; AHXIII/13の症例は, 繰り返す出 血の危険に常に曝されているので, とくに重篤な出血 がある場合は, 本疾患と診断され次第, 抗体を根絶す る為の免疫抑制療法を開始するべきである。

抗 FXIII/13-A 抗体が消失しない限り, 基礎疾患を
別表 4 免疫学的寛解後の凝血学的モニター頻度の基準 $(\text { (試案 })^{\mathrm{h})}$

\begin{tabular}{|c|c|c|}
\hline 寛解後の期間 & FXIII/13:Act & FXIII/13:Agn \\
\hline 6 力月以内 & 毎月 & 毎月 \\
\hline $6 \sim 12$ 力月 & 2, 3 力月毎 & 2, 3 力月毎 \\
\hline 12 力月以上* & 6 力月毎 & 6 力月毎 \\
\hline
\end{tabular}

*; 数年間は継続する

治療しても FXIII/13-A レベルが改善したり, 正常化 したりすることは期待できないが, AHXIII/13を誘発 したと思われる薬剤は中止することが望ましい.

(4) 抗体減少治療; 緊急の場合は, 血漿交換あるいは 免疫吸着療法の実施を考慮してもよい.

(5)長期的経過観察; AHXIII/13 は再燃するし，的確 に治療されないと突然出血死する可能性があるので, 完全寛解, 部分寛解の如何に拘らず，寛解後も定期的 且つ長期的に経過観察することが極めて大事である (別表 4).

\section{附 2. 抗 FXIII/13 同種抗体}

先天性/遺伝性 FXIII/13 欠損症の症例に, 抗 FXIII/13 同種抗体が発生する可能性がある。ただし，これまで に抗 FXIII/13-A 同種抗体が 7 例, 抗 FXIII/13-B 同種 
抗体は 1 例の報告があるのみである。FXIII/13 濃縮製 剂や組換え FXIII/13-A 製剂の治療的投与に対して, 症例の出血症状が反応しなくなった場合, 同種抗体の 出現を疑うべきである。その診断と治療は，自己抗体 の場合と同様であるが，既往反応/免疫増強効果によ り強く注意すべきであろう。

\section{用語についての注解}

FXIII/13 に関して用いられる用語と特性は, 国際血 栓止血学会/科学㧍よび標準化委員会の「FXIII/13 と フィブリノゲン小委員会」によって推奨されたもので ある゙．ただし，各種の論文や文書で，VIII，XII など ローマ数字の間違いがしばしばみられるので，医療安 全のためにアラビア数字を付記した.

\begin{tabular}{|c|c|}
\hline 属性 & 推奨される略語 \\
\hline 成熟タンパク質 & FXIII/13 \\
\hline 抗原 & FXIII/13:Agn \\
\hline $\mathrm{A}$ サブユニット & FXIII/13-A \\
\hline B サブユニット & FXIII/13-B \\
\hline FXIII/13-A 二量体 & FXIII/13-A \\
\hline FXIII/13-B 二量体 & FXIII/13-B 2 \\
\hline FXIII/13 四量体 & FXIII $/ 13-\mathrm{A}_{2} \mathrm{~B}_{2}$ \\
\hline 血漿 FXIII/13 & pFXIII/13 \\
\hline 細胞内 FXIII/13 & cFXIII/13 \\
\hline FXIII/13 因子凝固活性 & FXIII/13:Act \\
\hline 活性型 FXIII/13 & FXIII/13a \\
\hline
\end{tabular}

\section{参考文献}

a Ichinose A: Japanese criterion 2012 for the diagnosis and treatment of acquired hemorrhaphilia XIII/13. 58th Annual Meeting of the Scientific and Standardization Committee (SSC) of the International Society on Thrombosis and Hae- mostasis (ISTH), June 27-30, 2012, ACC Liverpool (Liverpool, England); Ichinose A: An update on Japanese criterion 2012 for the diagnosis and treatment of autoimmune/acquired hemorrhaphilia XIII/13; a proposal of algorithm of laboratory tests and differential diagnosis. XXIV Congress of the International Society on Thrombosis and Haemostasis, 59th SSC Program, Subcommittee session, June 29-July 4, 2013, Amsterdam RAI (Amsterdam, The Netherlands)

b Lorand L. Acquired Inhibitors of Fibrin Stabilization: A Class of Hemorrhagic Disorders of Diverse Origins. In: Green D ed. Anticoagulants Physiologic, Pathologic, and Pharmacologic. CRC Press, 1994:169-91.

c Egbring R, Kröniger A, Seitz R. Erworbene inhibitoren gegen Faktor XIII. Hamostaseologie. 1996;16:174-9.

d Rodeghiero F, Tosetto A, Abshire T, Arnold DM, Coller B, James P, Neunert C, Lillicrap D; ISTH/SSC joint VWF and Perinatal/Pediatric Hemostasis Subcommittees Working Group. ISTH/SSC bleeding assessment tool: a standardized questionnaire and a proposal for a new bleeding score for inherited bleeding disorders. J Thromb Haemost. 2010;8:20635 .

e Schulman S, Kearon C; Subcommittee on Control of Anticoagulation of the Scientific and Standardization Committee of the International Society on Thrombosis and Haemostasis. Definition of major bleeding in clinical investigations of antihemostatic medicinal products in non-surgical patients. $J$ Thromb Haemost. 2005;3:692-4.

f Baudo F, Collins P, Huth-Kühne A, Lévesque H, Marco P, Nemes L, Pellegrini F, Tengborn L, Knoebl P; EACH2 registry contributors. Management of bleeding in acquired hemophilia A: results from the European Acquired Haemophilia (EACH2) Registry. Blood. 2012;120:39-46

g Kohler HP, Ichinose A, Seitz R, Ariens RA, Muszbek L on behalf of the Factor XIII And Fibrinogen SSC Subcommittee Of The ISTH. Diagnosis and classification of factor XIII deficiencies. J Thromb Haemost. 2011;9:1404-6.

h Huth-Kühne A, Baudo F, Collins P, Ingerslev J, Kessler CM, Lévesque H, Castellano ME, Shima M, St-Louis J. International recommendations on the diagnosis and treatment of patients with acquired hemophilia A. Haematologica. 2009;94:56675 .

i Muszbek L, Ariëns RA, Ichinose A; ISTH SSC SUBCOMMITTEE ON FACTOR XIII. Factor XIII: recommended terms and abbreviations. J Thromb Haemost. 2007;5:181-3. 